\title{
THE LIPID DISTRIBUTION OF HUMAN PLATELETS IN HEALTH AND DISEASE ${ }^{1}$
}

\author{
BY BETTY N. ERICKSON, HAROLD H. WILLIAMS, IRA AVRIN, AND PEARL LEE \\ (From the Research Laboratory, Children's Fund of Michigan, and the Children's Hospital \\ of Michigan, Detroit)
}

(Received for publication September 27, 1938)

It is well established that the platelets play an important rôle in blood coagulation (1). When exposed by bleeding, they exhibit a characteristic physicochemical behavior (swelling, agglutination, excresence formation, and partial disruption (2)) resembling osmotic phenomena of phospholipids, e.g., myelin figure formation (3). In addition to serving physically in fibrin formation and clot retraction $(2,4)$, the platelets may liberate clot-aiding substances (5). There is some debate as to the exact nature of the factors liberated by platelet disintegration. There can be no doubt as to a thermostable thromboplastic agent which has been identified with cephalin $(5,6,7,8)$; it is questionable whether there is, in addition, a coagulant factor, either of prothrombin-like $(1,8)$ or different $(5,9)$ nature.

For a clearer definition of the modus operandi of platelets in blood coagulation, the present study has been focused upon their lipid composition in normal human blood and certain dyscrasias of blood coagulation in which platelet anomalies appear, namely, hemophilia and thrombopenic purpura. The data, furthermore, may contribute information concerning the genealogical relationship of platelets to other formed elements of the blood as well as to cellular structure in general.

The chemical studies of the platelets have included total lipid, free cholesterol, cholesterol esters, neutral fat, total phospholoid, cephalin, and nitrogen.

\section{METHODS}

Postabsorptive blood samples (usually 50 cc.) were drawn from the arm vein into a syringe containing 10 cc. of chilled anticoagulant solution. The blood was delivered into ice-cold flasks and adjusted to twice the original volume by adding anticoagulant solution.

Upon the first three pooled samples collected, a 10 per cent sodium citrate solution was employed as the

\footnotetext{
1 Presented before the American Society of Biological Chemists, 32d Annual Meeting, Baltimore, March 31, 1938. J. Biol. Chem., 1938, 123, xxxiv.
}

platelet preservative. A sodium metaphosphate solution ( 2.0 per cent sodium metaphosphate, ${ }^{2} 1.0$ per cent sodium chloride, and 0.2 per cent dextrose) proved more satisfactory (10) and was used for the later samples.

A suspension of intact platelets, virtually free of red and white blood cells, was prepared by slow-speed, differential centrifugation. The diluted blood was centrifuged in chilled, $15 \mathrm{cc}$., conical tubes for 10 minutes at 800 r.p.m. The diluted plasma containing some red and white cells was removed, placed in chilled tubes, and centrifuged again at low speed (800 r.p.m.) for five minutes. By this time the platelet suspension could be decanted, leaving a small sediment of red and white cells. The centrifugations for 5-minute periods, and decantation into clean, chilled tubes was repeated 10 to 15 times until no visible red cell sediment was thrown down.

A microscopic examination was made at this point to assure the absence of contaminating red and white blood cells. The platelets, at this stage, were intact, as indicated by the absence of clumping or gross changes in their appearance.

High-speed centrifugation (2,000 r.p.m. for two hours) of the suspension enabled separation of the platelets as a white sediment. This precipitate was washed twice with chilled anticoagulant solution (diluted 1:2) by shaking and recentrifugation, and then dried in vacuo at low temperatures.

About $10 \mathrm{mgm}$. of dried platelet material were secured from each individual $50 \mathrm{cc}$. sample of blood. At least five individual platelet preparations were pooled for each nitrogen and lipid distribution analysis by the microgasometric methods of Van Slyke, et al. $(11,12)$.

\section{CHEMICAL METHODS}

The lipids were extracted from the pooled, dried platelet samples by heating, under a reflux, on the water bath, with a 3:1 alcohol-ether mixture. The alcoholether extracts were evaporated in vacuo below $50^{\circ} \mathrm{C}$. in an atmosphere of nitrogen (13). The residue was extracted with petroleum ether, and total carbon and phosphorus determinations were made upon this extract by the micro-gasometric combustion procedures $(12,14)$. The phospholipids were precipitated from the petroleum ether extract according to the method of Bloor (15), and redissolved in moist ethyl ether. The phospholipids in this solution were determined upon aliquot portions

2 A special grade of sodium metaphosphate (a soluble polymer) can be obtained from Howe and French Company, Boston. 
by both the phosphorus (14) and oxidative titrimetric procedures (15). Another aliquant was hydrolyzed for the determination of choline in the choline-containing phospholipids (13). Inasmuch as cephalin contains no choline, the cephalin content can be calculated as the difference between the total phospholipid and the cholinecontaining phospholipid (13).

Modifications of the gasometric cholesterol method have been developed in this laboratory and employed for the analyses presented (12). The acetone-soluble fraction remaining after precipitation of the phospholipids was evaporated to dryness and extracted with petroleum ether. Aliquots of this extract were taken for the determination of total and free cholesterol. The free cholesterol and the saponified, re-extracted, total cholesterol samples (12) were measured into combustion tubes with conical bottoms, evaporated, dissolved in $1 \mathrm{cc}$. of ethyl alcohol, and precipitated with $0.2 \mathrm{cc}$. of a solution of one per cent digitonin in 50 per cent ethyl alcohol. The precipitates were dried thoroughly, washed with three $10 \mathrm{cc}$. portions of ethyl ether (centrifuging between each washing for 15 minutes), and dried. Then they were washed similarly with three $10 \mathrm{cc}$. portions of boiling water, dried, and combusted according to the microgasometric technique (12).

Nitrogen determinations were made on the dried, defatted platelets. Individual samples (5 to $10 \mathrm{mgm}$.) were weighed on a micro-balance for digestion and subsequent gasometric analysis (11). From this value and that of the total lipid the protein content of the original, fat-containing platelet sample was calculated.

\section{RESULTS AND DISCUSSION}

Platelets were collected from the blood of healthy adults ${ }^{3}$ in mixed groups of 5 and 10 , and separate groups of 5 men and 5 women, thus making four pooled samples representing 25 individual collections. There is substantial agreement in the lipid constituents among the four, pooled, platelet samples (Table I). Average values (per cent of dry weight) are: total lipid, 16 ; phospholipid, 12 ; free cholesterol, 2 ; cholesterol esters, 1; and neutral fat, 1. However, considerable variations appear in the protein values. The data suggest that this may be associated with the choice of anticoagulant solution used in preparing the samples. Consistently higher protein values are seen in the samples prepared with Olef's sodium metaphosphate solution (Table I) than in those prepared with sodium citrate.

8 These individuals, in the third or fourth decade of life, are associated with the laboratories of the Children's Fund of Michigan and the Children's Hospital of Michigan.
TABLE I

Composition of normal human platelets

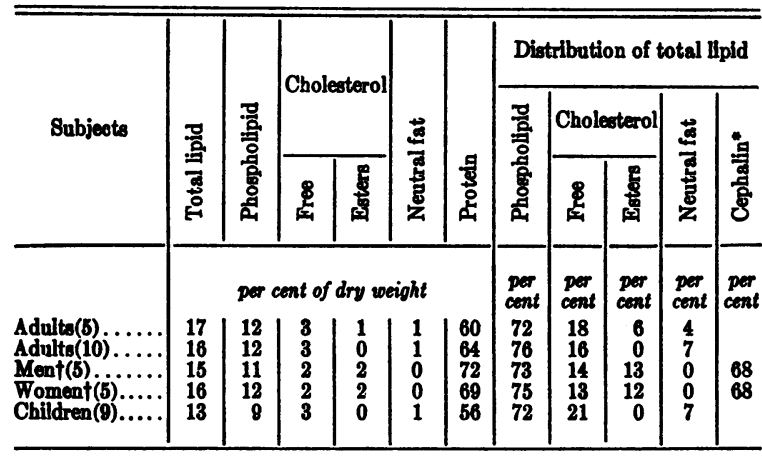

* Per cent of total phospholipid.

† Platelets collected with sodium metaphosphate solution (10); other samples with sodium citrate.

A sample of platelets was obtained from each of a group of 9 children (ages 4 to 8 years) who were under identical and rigidly controlled conditions of food intake and environment during the course of metabolic balance studies (16). The pooled, platelet sample from these children exhibited a slightly smaller amount of total lipid (13 per cent) than the samples from adults (16 per cent), the difference occurring in phospholipid content. The other constituents are comparable in amount (Table I).

The lipid composition of the platelet samples is found to be remarkably uniform when the individual lipid constituents are expressed as percentages of total lipid (Table I). About threefourths of the total lipid is phospholipid; onefourth, cholesterol (chiefly in the free unesterified form) ; and, small or negligible amounts, neutral fat. The data indicate that the major part of the phospholipid (68 per cent) is present as cephalin.

These quantitative analyses of human platelets are comparable to data on lipid extractives of horse platelets. The literature comprises one set of analyses by Haurowitz and Sladék (17), and two by Chargaff, Bancroft, and Stanley-Brown (7).

Comparison of the platelet composition with that of other blood cells is of interest from the viewpoint of blood cell interrelationships as well as cellular structure in general $(16,17,18,19$, 20). The platelets possess amounts of lipid similar to that found in leukocytes, on the basis of per cent of dry weight (Table II) (17). On the same basis, the erythrocytes contain only one- 
TABLE II

Composition of formed elements in blood

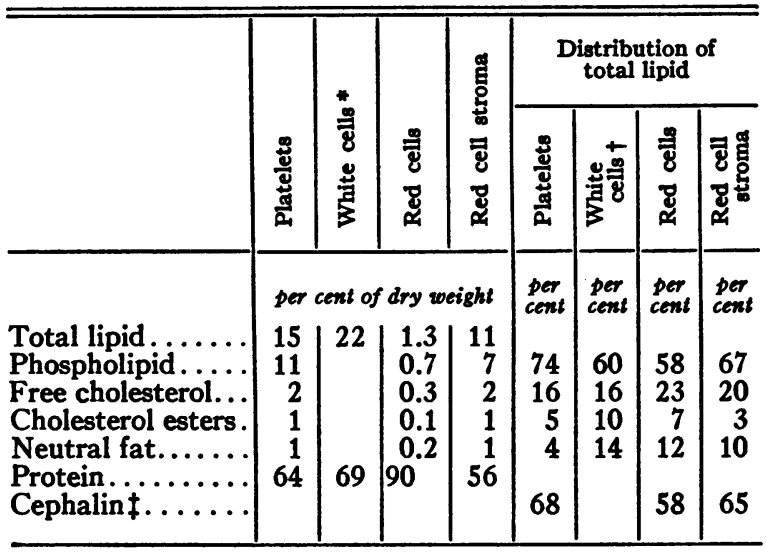

* From Haurowitz and Sladék (17).

$\dagger$ From Boyd (20).

$\ddagger$ Per cent of total phospholipid.

tenth as much lipid. However, the lipid content and distribution in red cells (calculated on a hemoglobin-free dry weight basis), and in erythrocyte stroma, separately determined (19), is strikingly similar to that of platelets. The uniformity of the lipid patterns (Table II) may indicate a typical chemical structure and close biological interrelationship of the red and white blood cells and platelets.

It is necessary to examine the physicochemical state of the lipid and protein $(19,21)$, and their association within the cells, for an explanation of the individual behavior of the platelets, erythrocytes, and leukocytes, with respect to surface phenomena : permeability and lability to osmotic lysis (22).

The platelets, which are seriously diminished in congenital thrombopenic purpura, are often restored to a normal concentration by splenectomy (23). Platelets were secured from one patient, during a temporary stimulation to a record count of several million per c.mm., soon after splenectomy. A single platelet sample, taken when the count had passed the peak but was still at four million, provided sufficient material for a complete analysis $(70 \mathrm{mgm}$. of dried platelets from $50 \mathrm{cc}$.

4 A 12-year-old girl, who had been under the observation of one of the authors (P.L.) for four years preceding splenectomy. Following splenectomy the platelet count soon reached, and was maintained, at a normal level. of blood in contrast to a normal yield of about 10 mgm.).

The lipid composition of the platelets in this sample of high platelet concentration (seven times normal) was not materially different from the composition determined in the samples from normal individuals (Table III). The apparent elevation of protein content may be caused by the use of sodium metaphosphate, rather than sodium citrate, as the anticoagulant.

TABLE III

Composition of human platelets in thrombopenic purpura after splenectomy, and in hemophitia

\begin{tabular}{|c|c|c|c|c|c|c|}
\hline & \multirow{2}{*}{$\begin{array}{l}\text { Throm- } \\
\text { bopenic } \\
\text { purpura }\end{array}$} & \multicolumn{3}{|c|}{ Hemophilia } & \multirow{2}{*}{$\underset{\begin{array}{c}\text { Nor- } \\
\text { mal } \\
\text { children }\end{array}}{\mid}$} & \multirow{2}{*}{$\begin{array}{c}\text { Nor- } \\
\text { mal } \\
\text { adults }\end{array}$} \\
\hline & & I & II & III & & \\
\hline 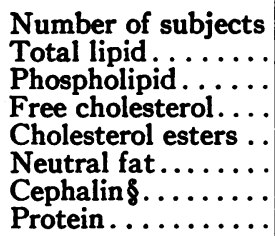 & $\begin{array}{c}1 \\
12 \\
9 \\
2 \\
0.1 \\
1 \\
66 \\
74\end{array}$ & $\begin{array}{r}5^{*} \\
12 \\
7 \\
2 \\
1 \\
2 \\
69 \\
72\end{array}$ & $\begin{array}{r}4^{*} \\
15 \\
10 \\
3 \\
1 \\
1 \\
63 \\
76\end{array}$ & $\begin{array}{c}3 \dagger \\
15 \\
9 \\
3 \\
0 \\
3 \\
66 \\
69\end{array}$ & $\begin{array}{c}9 \ddagger \\
13 \\
9 \\
3 \\
0 \\
1 \\
56\end{array}$ & $\begin{array}{l}25 \ddagger \\
16 \\
12 \\
2 \\
1 \\
1 \\
68 \\
66\end{array}$ \\
\hline
\end{tabular}

* Clotting time 2 to 5 hours.

† Clotting time 15 to 30 minutes.

$\ddagger$ Sodium citrate used as anticoagulant for all samples from children and 15 of the adults. Sodium metaphosphate solution (10) used for all others.

$\S$ Per cent of total phospholipid.

The work of many observers has led to a suspicion that one of the anomalies in hemophilia lies in a functional ineffectiveness of the blood platelets $(24,25,26)$. That the platelets do exhibit abnormal stability against disintegration has been demonstrated by dark-field microscopic examinations (27). They apparently undergo the initial phenomena of osmotic alterations, including a modified excrescence formation, but they do not suffer rapid lysis (27). These observations have been confirmed in the hematological investigations being carried on in conjunction with the present studies (28). The disintegration of hemophilic platelets (determined by incubation for 6 hours at $38^{\circ} \mathrm{C}$. in Olef's sodium metaphosphate solution) is negligible compared to the 40 per cent destruction of normal platelets. Differential platelet counts on the basis of size, initially and after incubation, demonstrate that the platelets are subject to measurable swelling (28).

Inasmuch as cholesterol and the various phospholipids are characterized by differences in their 
hydrophilic properties $(29,30)$, it is pertinent to search for clues to the anomalous behavior of hemophilic platelets within their own lipid constitution.

Nine individual platelet samples (combined as two samples for analysis) have been collected from the blood of five hemophiliacs ${ }^{5}$ with prolonged clotting times ( 2 to 5 hours). Three samples (pooled as one) were secured from three hemophiliacs ${ }^{5}$ with only slightly lengthened clotting times (15 to 30 minutes), but who had marked hemorrhagic symptoms and prolonged bleeding times. The hemophilic platelets possessed a normal quota of lipids (Table III) and showed no anomaly that could be detected by the present analytical methods.

On the basis of the lipid analyses it is of interest to calculate the amount of cephalin which may be contributed to the clotting mechanism by breakdown of the platelets. The platelets in 100 cc. of blood could furnish from 5 to $10 \mathrm{mgm}$. of cephalin (a concentration of one part in 10,000 ), if the entire amount in the platelets was liberated.

Extremely small amounts of "free" cephalin (of the order of one in several million) suffice for thrombin formation in the absence of excess antithrombin factors $(31,32)$. The significance of the observed amount of platelet cephalin depends upon the answers to the following queries: To what extent is blood clotting dependent upon platelet sources of phospholipids? How much of the cephalin is made "available" in the presence of the platelet proteins (9), plasma proteins (33), and electrolytes $(2,34)$ ?

These analytical data are significant to the extent of proving that there is no lack of the clotaiding type of phospholipids in the blood platelets of normal and hemophilic humans.

\section{SUMMARY}

Platelet samples from the blood of healthy men, women, and children, hemophiliacs, and a patient with thrombopenic purpura (following splenectomy) were collected and analyzed by micro-gaso-

5 The diagnosis of hemophilia in these individuals (ages 5 to 13 years) was established beyond question by clinical and laboratory observations over a period of several years (P.L.). metric methods for total lipid, total phospholipid, cephalin, free cholesterol and cholesterol esters, neutral fat, and nitrogen.

Lipid values (per cent of dry weight) on four pooled platelet samples (composite of five or more) from 25 adults, were uniform and averaged as follows: Total lipid, 16; phospholipid, 12; free cholesterol, 2; cholesterol esters, 1 ; neutral fat, 1 per cent. Cephalin composed 68 per cent of the total phospholipid.

The platelets from the blood of normal children (one sample made up of 9 individual collections) demonstrated a slightly lower value for phospholipid.

In hemophilia, the platelets appeared to possess normal amounts of the lipid constituents (12 samples pooled as 3 for analysis, and separated on the basis of clotting time).

The platelets secured from a patient with thrombopenic purpura, during the stimulated phase following splenectomy, exhibited a normal proportion of lipid constituents.

Similarities in the lipid composition of human platelets, leukocytes, erythrocytes, and stroma were pointed out and discussed.

\section{BIBLIOGRAPHY}

1. Howell, W. H., Theories of blood coagulation. Physiol. Rev., 1935, 15, 435.

2. Ferguson, J. H., Observations on the alterations of blood platelets as a factor in coagulation of the blood. Am. J. Physiol., 1934, 108, 670.

3. Leathes, J. B., Rôle of fats in vital phenomena. Lancet, 1925, 1, 803, 853, 957, 1019.

4. Tocantins, L. M., Platelets and the structure and physical properties of blood clots. Am. J. Physiol., 1936, 114, 709.

5. Mills, C. A., The rôle of platelets in blood clotting. Chinese J. Physiol., 1927, 1, 235.

6. Eagle, H., Studies on blood coagulation; rôle of prothrombin and of platelets in the formation of thrombin. J. Gen. Physiol., 1935, 18, 531.

7. Chargaff, E., Bancroft, F. W., and Stanley-Brown, M., Studies on the chemistry of blood coagulation. The chemical constituents of blood platelets and their role in blood clotting, with remarks on the activation of clotting by lipids. J. Biol. Chem., 1936, 116, 237.

8. Ferguson, J. H., An experimental analysis of coagulant activation. Am. J. Physiol., 1936, 117, 587.

9. Mills, C. A., Do blood platelets, plasma, and tissues yield thrombin or tissue fibrinogen? Am. J. Physiol., 1930, 95, 1. 
10. Olef, I., The rate of disintegration of platelets. J. Lab. and Clin. Med., 1936, 22, 128.

11. Peters, J. P. and Van Slyke, D. D., Quantitative Clinical Chemistry. Vol. II. Methods. Williams \& Wilkins Company, Baltimore, 1932, p. 353.

12. Kirk, E., Page, I. H., and Van Slyke, D.D., Gasometric microdetermination of lipids in plasma, blood cells and tissues. J. Biol. Chem., 1934, 106, 203.

13. Williams, H. H., Erickson, B. N., Avrin, I., Bernstein, S. S., and Macy, I. G. Determination of cephalin in phospholipids by the estimation of choline. J. Biol. Chem. 1938, 123, 111.

14. Kirk, E., Gasometric microdetermination of phosphoric acid. J. Biol. Chem., 1934, 106, 191.

15. Bloor, W. R., The oxidative determination of phospholipid (lecithin and cephalin) in blood and tissues. J. Biol. Chem., 1929, 82, 273.

16. Erickson, B. N., Williams, H. H., Hummel, F. C., and Macy, I. G., The lipid and mineral distribution in the serum and erythrocytes of normal children. J. Biol. Chem., 1937, 118, 15.

17. Haurowitz, F. and Sladék, J., Uber die Chemische Zusammensetzung der Blutplättchen. Ztschr f. physiol. Chem., 1928, 173, 233.

18. Bernstein, S. S., Jones, R. L., Erickson, B. N., Williams, H. H., Avrin, I., and Macy, I. G., A method for the preparation of posthemolytic residue or stroma of erythrocytes. J. Biol. Chem., 1938, 122, 507.

19. Erickson, B. N., Williams, H. H., Bernstein, S. S., Avrin, I., Jones, R. L., and Macy, I. G., The lipid distribution of posthemolytic residue or stroma of erythrocytes. J. Biol. Chem., 1938, 122, 515.

20. Boyd, E. M., The lipid content of the white blood cells in normal young women. J. Biol. Chem., 1933, 101, 623.

21. Beach, E. F., Erickson, B. N., Bernstein, S. S., and Williams, H. H., Basic amino acid content of posthemolytic residue or stroma of erythrocytes. J. Biol. Chem. (Proc.), 1938 123, vi.
22. Silberberg, N., The causes and mechanism of thrombosis. Physiol. Rev., 1938, 18, 197.

23. Brown, D. N., and Elliott, R. H. E., The results of splenectomy in thrombocytopenic purpura. J. A. M. A., 1936, 107, 1781.

24. Minot, G. R. and Lee, R. I., The blood platelets in hemophilia. Arch. Int. Med., 1916, 18, 474.

25. Howell, W. H. and Cekada, E. B., The cause of the delayed clotting in hemophilic blood. Am. J. Physiol., 1926, 78, 500.

26. Christie, R. V., Davies, H. W., and Stewart, C. P., Studies in blood coagulation in haemophilia. I. Blood coagulation in hemorrhagic diseases. Observations on haemic functions in haemophilia. Quart. J. Med., 1926-27, 20, 481.

27. Harrow, B. and Sherwin, C. P., Textbook of Biochemistry. Chap. XV. Blood-Ferguson, J. H. W. B. Saunders Co., Philadelphia, 1935.

28. Lee, Pearl and Erickson, Betty N., Platelet studies in normal men and women (menstruating and nonmenstruating) and subjects with bleeding disorders: Counts, disintegration rates and intradermal platelet injections. Proc. Soc. Exper. Biol. and Med. (In press.)

29. Maclean, H. and Maclean, I. S., Lecithin and Allied Substances-the Lipins. Longmans, Green and Co., London, 1927.

30. Bull, H. B., The Biochemistry of the Lipids. Burgess Publishing Co., Minneapolis, 1935.

31. Spagnol, G., Cephalins and blood coagulability. Rev. sud.-am. de endocrinol., 1934, 17, 619. Chem. Abst., 1935, 29, 226.

32. Ferguson, J. H., Quantitative relationships of calcium and cephalin in experimental thrombin formation. Am. J. Physiol., 1938, 123, 341.

33. Page, I. H., Chemistry of the Brain. Charles C. Thomas, Baltimore, 1937, p. 278.

34. Ferguson, J. H., The blood calcium and the calcium factor in blood coagulation. Physiol. Rev., 1936, 16,640 . 